\title{
The Annenskiy thermal waters as the certain stage of the water-rock interaction (Far East, Russia)
}

\author{
Elena Zippa ${ }^{1,2,3, *}$, Ivan Bragin ${ }^{3}$, George Chelnokov ${ }^{3}$, and Natalia Kharitonova ${ }^{3,4}$ \\ ${ }^{1}$ Tomsk Branch of the Trofimuk Institute of Petroleum Geology and Geophysics SB RAS, Tomsk, \\ Russia \\ ${ }^{2}$ National Research Tomsk Polytechnic University, Tomsk, Russia \\ ${ }^{3}$ Far East Geological Institute FEB RAS, Vladivostok, Russia \\ ${ }^{4}$ Lomonosov's Moscow State University, Moscow, Russia
}

\begin{abstract}
Chemical composition and saturation degree of the Annenskiy thermal waters to minerals of water-bearing rock have been considered in the manuscript. It is shown that the thermal waters are low mineralized, alkaline and belong to $\mathrm{HCO}_{3}-\mathrm{Na}$ type. The thermal waters-rock system is equilibrium-nonequilibrium. It means that the waters dissolve primary minerals continuously, never reaching saturation (anorthite, K-field spar and etc.), and form new secondary mineral phases simultaneously, reaching saturation (gibbsite, montmorillonite, albite and etc.). Besides, peculiarities of the equilibrium with minerals of water-bearing rocks for surface and ground waters of the studied region was considered. It is established that the thermal waters are ahead of surface and ground waters and represent the certain stage of the water-rock system evolution. The stage is characterized by the certain chemical composition (TDS $=148$ $317 \mathrm{mg} / \mathrm{L}, \mathrm{HCO}_{3}-\mathrm{Na}, \mathrm{SiO}_{2}=9-80 \mathrm{mg} / \mathrm{L}$ ), complex of secondary minerals (calcite, albite, laumontite and etc.) and special geochemical environment (pH 8.2-8.6).
\end{abstract}

\section{Introduction}

Thermal waters are distributed around the world and attract the attention of many scientists. The most discussed issue in case of thermal waters is the processes and mechanism of their chemical composition formation.

It should be noticed that the series of manuscripts are dedicated to the origin of thermal waters of the Far East, Russia [1-3]. However, the formation processes of the Annenskiy thermal waters has never been considered before in accordance with the concept of the geological evolution of the water-rock system. This approach was used for thermal waters in other regions and results were published only in a few manuscripts [4-6]. In the mentioned authors' opinion, thermal waters, particularly nitrogen-rich ones, represent the certain stage of evolution of the water-rock system, which is in the equilibrium-

* Corresponding author: zev-92@mail.ru 
nonequilibrium state. This state signifies that water continuously dissolves endogenous minerals and has never reached equilibrium with them, but simultaneously forms secondary minerals because equilibrium with these minerals is reached [7]. According to the mentioned concept, each stage of evolutional development of the water-rock system is characterized by the certain geochemical type of water, a complex of secondary minerals and special geochemical environment [7].

Therefore, the purpose of the current manuscript is to study the chemical composition of the Annenskiy thermal waters, their equilibrium with minerals of host rocks and represent their formation processes and mechanisms as a certain stage of the water-rock system evolution.

\section{Geology and hydrogeology}

The Annenskiy thermal spring is located in the Khabarovskiy region, Russia, in the lower reaches of the Amur River, on its right bank, $120 \mathrm{~km}$ upstream from the town of Nikolaevsk-on-Amur, $6.5 \mathrm{~km}$ to the southwest from the Susanino pier [1-3] (Fig. 1).

This type of thermal waters wide spreads in the Far East Russia and related with young tectonic activity of the region. The host rocks of the Annenskiy thermal spring are tuffs and tuffaceous sandstones of Cretaceous age.

Hydrogeological conditions of the studied thermal waters are entirely determined by tectonic factors. They circulate along faults of shear and fracture zones. The manifestations of thermal waters are confined to the zone of disturbance of the northeast strike. Within the zone with a thickness of 30-40 m, the rocks are strongly

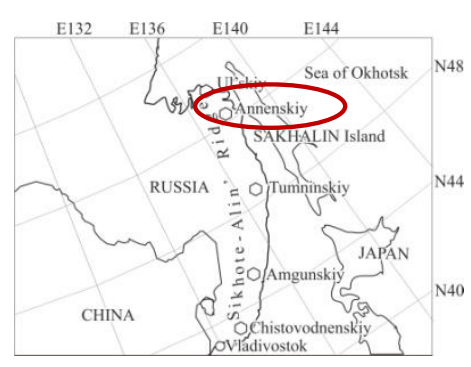

Fig. 1. Schematic map of Annenskiy thermal waters location, Far East of Russia. crushed and almost everywhere hydrothermally altered. Cracks and veins of the fault zone are direct conductors of thermal waters and mostly confined to tuff-conglomerates and tectonic breccias.

\section{Materials and methods}

This research is based on the results of hydrochemical monitoring that was conducted in 2007-2018. The thermal springs were sampled for chemical and isotopic composition. Rapidly changing parameters $(\mathrm{pH}$, temperature, and electrical conductivity) were determined in situ. The samples were filtered in the field using membrane filter with $0.45 \mu \mathrm{m}$ pore size. The analysis of surface and ground waters chemical composition of was carried out as well.

The nature of the thermal waters' equilibrium with primary and secondary minerals was calculated in accordance with known methods developed by [8] and illustrated on the diagrams of minerals stability. The diagrams were drawn for temperatures of $5^{\circ} \mathrm{C}$ for surface and underground waters and $50^{\circ} \mathrm{C}$ for the thermal waters. The mineral saturation indexes (SI) of water samples were calculated using the Geochemist's Workbench software [9] at the springs' temperature. The saturation index is defined as

$$
S I=\log (Q / K) \text {, }
$$

where $\mathrm{Q}$ is the reaction quotient (or ion activity product) and $\mathrm{K}$ is the equilibrium constant at a given temperature and pressure. In the case when $\mathrm{SI}=0$ water is in equilibrium with the mineral and no dissolution or precipitation should take place. SI $>0$ indicates that 
the solution is supersaturated with respect to a given mineral; $\mathrm{SI}<0$ indicates undersaturation.

\section{Hydrochemistry}

The chemical composition of Annenskiy thermal waters is considered for 19 boreholes. The temperature of the waters varies from 20 to $48^{\circ} \mathrm{C}$. The TDS values do not exceed $0.4 \mathrm{~g} / \mathrm{L}$ a vary from 148 to $317 \mathrm{mg} / \mathrm{L}$. In spite of the low salinity, $\mathrm{pH}$ values predominantly change between 8.2 and 8.6. There is exclusion where $\mathrm{pH}$ value is 6.5 and temperature is $20{ }^{\circ} \mathrm{C}$ that probably indirectly indicates mixing of thermal waters with colder and more acid groundwaters.

As it was previously shown, the Annenskiy hot springs are $\mathrm{Na}-\mathrm{HCO}_{3}$ waters with high content of $\mathrm{N}_{2}$ gas [1]. This type of thermal waters is observed for other regions as well [4-6]. Besides, the fact of low TDS and high $\mathrm{pH}$ was explained in the mentioned papers.

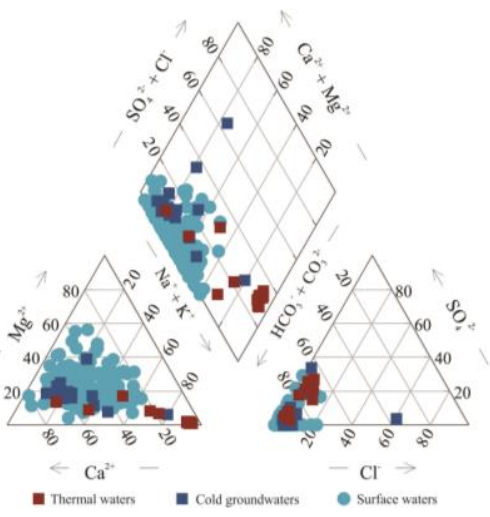

Fig 2. Chemical composition of the Annenskiy waters.

Generally, the dominant anion is $\mathrm{HCO}_{3}{ }^{-}$in the Annenskiy thermal waters. Concentrations of $\mathrm{HCO}_{3}{ }^{-}$vary from 57.9 to $207.4 \mathrm{mg} / \mathrm{L}$. There are some cases where concentrations of $\mathrm{SO}_{4}{ }^{2-}$ are competitive to $\mathrm{HCO}_{3}{ }^{-}$content, values change $6-35 \mathrm{mg} / \mathrm{L}$. Concentrations of $\mathrm{Cl}^{-}$do not exceed $9.5 \mathrm{mg} / \mathrm{L}$. Among cations, concentrations of $\mathrm{Ca}^{2+}$, $\mathrm{Mg}^{2+}$, and $\mathrm{K}^{+}$are low in comparison to $\mathrm{Na}^{+}(12-69 \mathrm{mg} / \mathrm{L})$. An exception is 3 wells where the content of $\mathrm{Ca}^{2+}$ is higher than $\mathrm{Na}^{+}$and, probably, is the result of mixing thermal and cold groundwaters. Unlike $\mathrm{Ca}^{2+}, \mathrm{Mg}^{2+}$ and $\mathrm{K}^{+}$concentrations of $\mathrm{SiO}_{2}$ are quite high and rate from 9 to $80 \mathrm{mg} / \mathrm{L}$. According to the chemical composition, Annenskiy thermal waters predominantly belong to $\mathrm{HCO}_{3}-\mathrm{Na}$ type and changes from $\mathrm{HCO}_{3}-\mathrm{Ca}$ (1 well) to $\mathrm{HCO}_{3}-\mathrm{SO}_{4}-$ $\mathrm{Na}$ through $\mathrm{HCO}_{3}-\mathrm{Na}-\mathrm{Ca}$ and $\mathrm{HCO}_{3}-\mathrm{Na}$ types (Fig. 2).

The cold groundwaters within Annenskiy deposit are also characterized by low TDS which does not exceed $0.5 \mathrm{~g} / \mathrm{L}$. The groundwaters are slightly acid or neutral, $\mathrm{pH}$ values rate between 6.3 and 7.9. Temperature changes from 2.8 to $16.8^{\circ} \mathrm{C}$. The $\mathrm{HCO}_{3}{ }^{-}$ion is predominant among anions excluding a couple of cases where dominance pass to $\mathrm{SO}_{4}{ }^{2-}$ and $\mathrm{Cl}^{-}$. Obviously, cations content is characterized by $\mathrm{Ca}^{2+}$ dominance, in several cases by the dominance of $\mathrm{Na}^{+}$, rarely $-\mathrm{Mg}^{2+}$. Generally, the cold groundwaters belong to $\mathrm{HCO}_{3}-\mathrm{Ca}$ type, with fewer $\mathrm{HCO}_{3}-\mathrm{Ca}-\mathrm{Na}, \mathrm{HCO}_{3}-\mathrm{Na}, \mathrm{HCO}_{3}-\mathrm{SO}_{4}-\mathrm{Ca}-\mathrm{Mg}$, in a single case to $\mathrm{Cl}-\mathrm{HCO}_{3}-$ Ca.

The salinity of the surface waters is $32-309 \mathrm{mg} / \mathrm{L}$. According to $\mathrm{pH}$ values that vary from 5.4 to 7.2 , the surface waters are slightly acid and neutral. Their chemical composition is characterized by the absolute dominance of $\mathrm{HCO}_{3}^{-}$among anions, however, cations content is quite mixed (Fig. 2).

\section{Water-rock interaction}

Previously, it was established that the water-rock system is capable of progressive evolution, which ensures the continuous growth of increasingly complex structures and phenomena [7]. The water-rock system evolution proceeds in several stages. Each stage of the evolution is accompanied by the formation of secondary minerals, respective 
geochemical type of waters and geochemical environment. There is a strong genetical connection between these characteristics of the evolutional stage. The complex of secondary minerals, their geochemical properties and variety of chemical elements in the solution impact the geochemical conditions. In turn, all these have an influence on minerals dissolution and precipitation processes and peculiarities of formation of natural waters chemical composition [7].

Therefore, for understanding the processes and mechanisms of thermal waters formation, it is important to know which stage of the water-rock system evolution the considered waters belong to. Consequently, it is necessary to observe not only the type of the waters but also their saturation degree with water-bearing rock minerals.

The equilibrium of the Annenskiy thermal waters is considered below. Previous studies showed [10] that, according to the isotopic composition of $\mathrm{H}$ and $\mathrm{O}$, Annenskiy thermal waters referred to meteoric type, because thermal waters fell along the meteoric water line. In addition, the saturation of surface and groundwaters of Annenskiy deposit has been estimated for tracking the processes of the water-rock system evolution.

The thermodynamic calculation results showed that the thermal waters and a minority of cold groundwaters were equilibrium with calcite, but the surface waters were far from saturation to this mineral (Fig. 3 a).
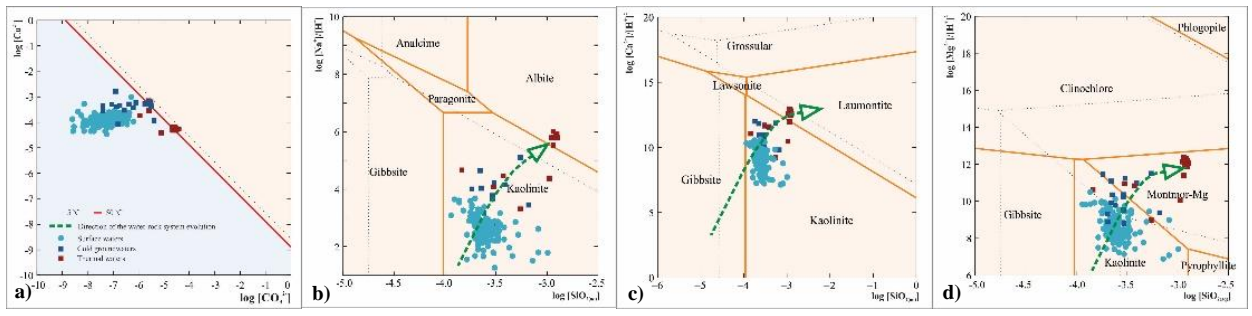

Fig. 3. Equilibrium of Annenskiy waters with calcite (a) and aluminosilicate minerals in the system $\mathrm{HCl}-\mathrm{H}_{2} \mathrm{O}-\mathrm{Al}_{2} \mathrm{O}_{3}-\mathrm{Na}_{2} \mathrm{O}-\mathrm{SiO}_{2}(\mathrm{~b})$, in the system $\mathrm{HCl}-\mathrm{H}_{2} \mathrm{O}-\mathrm{Al}_{2} \mathrm{O}_{3}-\mathrm{CaO}-\mathrm{SiO}_{2}$ (c), in the system $\mathrm{HCl}-\mathrm{H}_{2} \mathrm{O}-\mathrm{Al}_{2} \mathrm{O}_{3}-\mathrm{MgO}-\mathrm{SiO}_{2}(\mathrm{~d})$ at 5 and $50{ }^{\circ} \mathrm{C}$.

Carbonate solubility decreases with increasing temperature and, consequently, equilibrium degree of waters with calcite increases. Therefore, the saturation with respect to calcite is attained only in thermal waters with a temperature above $28{ }^{\circ} \mathrm{C}$ (Fig. 4d), despite there low salinity $(190-283 \mathrm{mg} / \mathrm{L})$ and extremely low concentrations of $\mathrm{Ca}^{2+}(2-4 \mathrm{mg} / \mathrm{L})$ and alkalinity about $100 \mathrm{mg} / \mathrm{L}$ (Fig. 4a, b). Besides, $\mathrm{pH}$ is another factor, controlling saturation state to calcite, which is attained when $\mathrm{pH}$ values exceed 8.0. But there are some wells where equilibrium with calcite was attained at $\mathrm{pH}=7.4$ because the $\mathrm{Ca}^{2+}$ content is significantly higher (35.6-38.3 mg/L) (Fig. 4a).
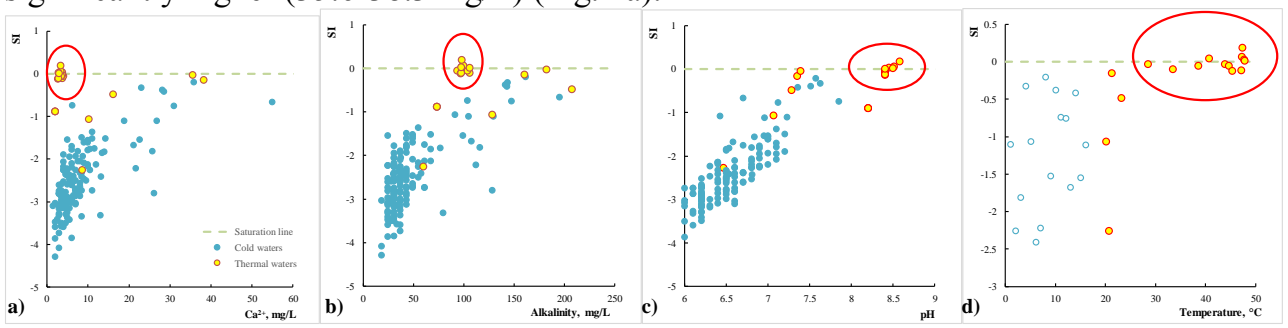

Fig. 4. Dependence of saturation index for calcite on $\mathrm{Ca}^{2+}$ (a), alkalinity (b), $\mathrm{pH}(\mathrm{c})$, temperature (d) of Annenskiy waters.

The studied waters exhibited a more complex equilibrium with aluminosilicate minerals (Fig. 3 b-d). There is a clearly defined group of thermal waters, located significantly upper 
than surface waters and groundwaters. This means that thermal waters if they are not mixed with groundwaters, are ahead of surface and ground waters from the point of view of the water-rock system evolution.

It is shown in the diagrams of minerals stability, surface waters and groundwaters are located in the field of kaolinite's stability and equilibrium with respect to gibbsite and kaolinite. In turn, the majority of thermal waters are located in the stability fields of albite, laumontite, and $\mathrm{Mg}$-montmorillonite that means the waters are saturated with respect to gibbsite, kaolinite, montmorillonite, albite, and laumontite. Additionally, the equilibrium state of some hot waters is similar to groundwaters, probably, because of their mixing.

On the other hand, all types of Annenskiy waters are far from equilibrium with primary aluminosilicates such as paragonite, grossular, anorthite and etc.

\section{Conclusion}

The Annenskiy thermal wares and water-bearing rocks represent a unique equilibriumnonequilibrium system [7]. It means, on the one hand, thermal waters are not saturated with respect to minerals which continuously dissolve (anorthite, K-field spar and etc.), one the other hand, they simultaneously equilibrium with minerals (gibbsite, kaolinite, calcite, talc and etc) which are formed during the water-rock interaction time.

The first secondary formed mineral is gibbsite. In result of gibbsite appearances, the proportion of $\mathrm{Al}$ and $\mathrm{Si}$ changes. Al content decreases because the major part was bound by gibbsite, but $\mathrm{Si}$ continues to grow as its concentrations are significantly higher in the rocks than Al. The next secondary formed mineral is kaolinite. Kaolinite formation is determined by the amount of entering the solution Al. The majority of groundwaters and surface waters settled in this stage of water-rock evolution. In case of thermal waters, over the time, the water-rock system continues to evolve and attains the stage of montmorillonite formation and after this - calcite formation.

The equilibrium of the waters with clay and carbonate minerals is a geochemical barrier for accumulation $\mathrm{Ca}, \mathrm{Mg}, \mathrm{Fe}, \mathrm{K}$ and $\mathrm{Al}$ in the solution. In addition, $\mathrm{pH}$ values of the waters increase what accelerate processes of secondary minerals formation. Nevertheless, aluminosilicates dissolution continues to supply the waters with chemical elements. Over a longer time of the water-rock interaction, the thermal waters attain equilibrium with laumontite, talc, albite and settle in the stage of albite formation.

To summarize, the Annenskiy thermal waters and water-bearing rocks represents the certain stage of the water-rock system evolution. This stage of evolution is defined by the geochemical type of the waters, the complex of secondary minerals and the certain geochemical environment.

This study was made under the support of Russian science foundation, grant № 18-77-10007.

\section{References}

1. I.V. Bragin, G.A. Chelnokov, O.V. Chudaev, N.A. Kharitonova, S.V. Vysotskiy, Acta geological Sinica, 90 (1), 276-284 (2016)

2. G.A. Chelnokov, I.V. Bragin., N.A. Kharitonova, Journ. of Hydrol., 559, 942-953 (2018)

3. O.V. Chudaev, V.A. Chudaeva, I.V. Bragin, Rus. Journ. of Pacific Geol., 27 (6), 73-81 (2008)

4. A.M. Plyusnin, L.V. Zamana, S.L. Shvartsev, O.G. Tokarenko, M.K. Chernyavskii, Russ. Geol. Geophys., 54 (5), 647-664 (2013) 
5. S.L. Shvartsev, Z. Sun, S.V. Borzenko, B. Gao, O.G. Tokarenko, E.V. Zippa, Appl.Geoch., 96, 113-130 (2018)

6. S.L. Shvartsev, L.V. Zamana, A.M. Plyusnin, O.G. Tokarenko, Geochem. Int., 53 (8), 713-725 (2015)

7. S.L. Shvartsev, Geochem. Int., 46 (13), 1285-1398 (2008)

8. R.M. Garrels, C.L. Christ. Harper and Row, New York, 450 (1965)

9. C.M. Bethke, B. Farrell, S. Yeakel, LLC, Champaign, Illinois, US. (2018)

10. N.A. Kharitonova, G.A. Chelnokov, I.V. Bragin, E.A. Vakh, Russian Journ. of Pacific Geol., 31 (2), 75-86 (2012) 